\title{
Russian Enterprises in Spring 2021: What Has Changed during the Covid-19 Pandemic Year
}

\author{
D. B. Kuvalin ${ }^{a}$, Yu. V. Zinchenko ${ }^{a}$ *, and P. A. Lavrinenko ${ }^{a}$ \\ ${ }^{a}$ Institute for National Economic Forecasting, Russian Academy of Sciences, Moscow, Russia \\ *e-mail:yvzinch@gmail.com \\ Received June 29, 2021; revised July 1, 2021; accepted July 5, 2021
}

\begin{abstract}
The paper analyzes and comments on the results of a regular survey of Russian enterprises in the real sector, which was conducted by the Institute for National Economic Forecasting of the Russian Academy of Sciences. The assessments of enterprises regarding the quality of the anticrisis policy of the state during the pandemic are presented. The information on the investment activity of Russian enterprises and on the sources of its financing is reflected. The opinions of enterprises on the importance for them of the exchange rate of the ruble against the US dollar and the euro, as well as on the desired dynamics of this rate are presented. The problem of the use of outsourcing by Russian enterprises and the presence of geographically separate subdivisions is investigated. The activity of Russian enterprises on the processing of their waste into secondary raw materials and on their use in primary production is considered.
\end{abstract}

Keywords: a survey of enterprises, anticrisis policy during the COVID-19 pandemic, investment activity of Russian enterprises, the impact of the exchange rate, waste processing, recycling, use of secondary raw materials

DOI: $10.1134 / \mathrm{S} 1075700721060095$

In the spring of 2021, despite the continuation of the COVID-19 pandemic, a noticeable revival began in the Russian economy. The revival was facilitated by several factors: the rapid growth in world prices for many key Russian exports (ferrous and non-ferrous metals, natural gas, chemical products, grain, etc.) and an increase in the physical volume of exports, which began back in 2020 [1, 2]; further easing of quarantine restrictions; preservation of some of the measures for state support of the population and enterprises; rapid growth in industries that produce products that are in demand during the pandemic.

As a result, in January-April 2021, the volume of industrial production increased by $1.1 \%$ in relation to January-April 2020 according to the estimates of the Federal State Statistics Service. If the growth in industrial production in January-April 2021 is compared in relation to the same period in precrisis 2019, then the Federal State Statistics Service estimates it at $+1.7 \%$, and the Center for Macroeconomic Analysis and Short-Term Forecasting estimates at $+2.6 \%$ [3, 4]. Investments in fixed assets also gradually grew, continuing the trend that began as early as 2020 . Compared to the previous quarter, the volume of investments increased: by $1.3 \%$ in July-September 2020, by $2.9 \%$ in October-December 2020 , and by $1.2 \%$ in January-March 2021 [4].
At the same time, an abrupt rise in prices on world markets led to an acceleration of inflation within the country as well: as a result, the Bank of Russia began tightening its monetary policy, which will inevitably restrain economic recovery. In addition, many of the risks associated with the ongoing COVID-19 pandemic remained in full, including the risks of new restrictions on a number of economic activities.

A survey of Russian enterprises conducted by the Institute for National Economic Forecasting of the Russian Academy of Sciences in April-May $2021^{1}$ also testifies to the contradictoriness of the situation in the domestic economy. On the one hand, there are positive trends in some areas. On the other hand, these shifts for the better usually are not too significant, and in some cases there are no improvements at all.

An encouraging trend is an increase in the share of Russian enterprises that believe that they have not been affected by the pandemic. While in April-May 2020 there were $4.80 \%$ of such enterprises, and in November-December 2020 their share was $11.03 \%$, in April-May 2021 their share was already $22.90 \%$.

\footnotetext{
${ }^{1}$ The survey involved 154 enterprises (power industry; water supply; ferrous and non-ferrous metallurgy; chemistry; mechanical engineering; building materials industry; forestry, woodworking and pulp and paper industries; light, food, pharmaceutical and printing industries; agriculture; construction; transport; health care; trade; public catering) from 54 regions of Russia.
} 
Table 1. Answers to the question: "Has your enterprise been affected by the events associated with the coronavirus pandemic?" (sum of answers $=100 \%$ )

\begin{tabular}{l|c|c|c}
\hline \multicolumn{1}{c|}{ Period } & Yes & No & $\begin{array}{c}\text { No, but it may } \\
\text { be affected in the future }\end{array}$ \\
\hline $\begin{array}{l}\text { April-May 2020 } \\
\text { November-Decem- }\end{array}$ & 73.60 & 4.80 & 21.60 \\
ber 2020 & 11.03 & 19.85 \\
April-May 2021 & 71.90 & 22.90 & 5.20 \\
\hline
\end{tabular}

Table 2. Answers to the question: "Has your company managed to take advantage of the support measures promised by the federal authorities in connection with the coronavirus pandemic?" (sum of answers $=100 \%$ )

\begin{tabular}{l|r|c|c}
\hline \multicolumn{1}{c|}{ Period } & Yes & No & $\begin{array}{c}\text { No, but this } \\
\text { is expected to be done } \\
\text { in the future }\end{array}$ \\
\hline $\begin{array}{l}\text { April-May 2020 } \\
\begin{array}{l}\text { November-Decem- } \\
\text { ber 2020 }\end{array}\end{array}$ & 24.82 & 68.61 & 20.50 \\
April-May 2021 & 30.46 & 66.23 & 6.57 \\
\hline
\end{tabular}

Table 3. Answers to the question: "Has your company managed to take advantage of the support measures promised by the regional authorities in connection with the coronavirus pandemic?" \% (sum of answers $=100 \%$ )

\begin{tabular}{c|c|c|c}
\hline Period & Yes & No & $\begin{array}{c}\text { No, but this } \\
\text { is expected to be done in } \\
\text { the future }\end{array}$ \\
\hline April-May 2020 & 5.70 & 77.20 & 17.10 \\
April-May 2021 & 8.90 & 84.25 & 6.85 \\
\hline
\end{tabular}

Admittedly, the share of enterprises affected by the pandemic remains much more significant and indicates the serious damage that domestic producers of goods and services have suffered over the past year (Table 1).

Over the past year since the introduction of pandemic restrictions, the proportion of enterprises that reported receiving support from the state has notice- ably increased. In particular, while in April-May 2020 $9.00 \%$ of responding enterprises received assistance from the federal authorities, by November-December 2020 there were already $24.83 \%$ of such enterprises, and in April-May 2021 their share was 30.46\% (Table 2). The share of enterprises that have received support from regional authorities has also slightly increased from $5.70 \%$ in April-May 2020 to $8.90 \%$ in AprilMay 2021 (Table 3).

In addition, over the past year, there has been a positive shift in the assessments by domestic enterprises of measures of economic support from the Russian authorities. In particular, the share of respondents who believe that everything is being done correctly and that mistakes are insignificant has grown noticeably from $5.60 \%$ in April-May 2020 to $18.50 \%$ in April-May 2021. The share of opinions that "in general, everything is being done well, despite significant shortcomings" has also increased over the year from $16.90 \%$ to $29.60 \%$. At the same time, the share of assessments "bad" and "very bad" has decreased significantly (Table 4).

In other words, with all the reservations, almost $80 \%$ of Russian enterprises saw significant positive effects of the authorities' anticrisis policy in the spring of 2021. This circumstance confirms the opinion that the rapid cessation of such a policy is undesirable [57]. In this regard, the behavior of the Bank of Russia, which raised the key rate from $4.25 \%$ in January 2021 to $5.50 \%$ in June 2021, has aroused great questions. Such an action will inevitably restrain the economic activity of domestic enterprises, a very significant part of which directly links their investment plans with the cost of loans (Table 5).

The increase in the cost of the loan looked completely untimely because, as the survey results showed, there was no growth in the investment activity of enterprises during the pandemic. The share of enterprises that implemented investment projects has turned out to be lower in the spring of 2021 than a year earlier (Table 6). The share of enterprises intending to launch new investment projects in the next $1-2$ years was higher in the spring of 2021 than a year earlier, but not by much (Table 7). Moreover, the investment

Table 4. Answers to the question: "How do you assess the activities of the government in providing economic support to enterprises affected by the coronavirus pandemic?" (sum of answers $=100 \%$ )

\begin{tabular}{c|c|c|c|c|c}
\hline Period & $\begin{array}{c}\text { Everything is done } \\
\text { correctly, if there } \\
\text { are shortcomings, they } \\
\text { are insignificant }\end{array}$ & $\begin{array}{c}\text { Generally not bad, } \\
\text { but there are also } \\
\text { significant } \\
\text { shortcomings }\end{array}$ & $\begin{array}{c}\text { Satisfactory, there are } \\
\text { no less shortcomings } \\
\text { than correct } \\
\text { decisions }\end{array}$ & $\begin{array}{c}\text { Poor, there are more } \\
\text { shortcomings than } \\
\text { correct decisions }\end{array}$ & $\begin{array}{c}\text { Very bad, there } \\
\text { are many serious } \\
\text { mistakes }\end{array}$ \\
\hline April-May 2020 & 5.60 & 16.90 & 31.60 & 27.40 & 18.50 \\
April-May 2021 & 18.50 & 29.60 & 31.10 & 19.30 & 1.50 \\
\hline
\end{tabular}


activity of Russian enterprises still cannot return to the level that took place before the crisis of 2014-2015.

Such stagnation in the field of investment activity is explained, in particular, by the lack of finance. The proportion of responses about an increase in investment financing from their own funds in the spring of 2021 was at the minimum level over the past 20 years, $17.24 \%$ (Table 8). The share of answers about an increase in investment financing from external sources in the spring of 2021 was also at a very low level, $6.78 \%$ (Table 9).

As for the contribution of various sources to investment financing, enterprises' own funds still prevail with a large preponderance being $86.99 \%$ of responses in the spring of 2021. At the same time, over the last year, the share of reports on investment lending on the part of Russian banks has increased to $43.15 \%$, and this is undoubtedly good news.

The contribution of other sources remains insignificant, although here we should note an increase in the frequency of reports on financing investments from the federal budget of up to $11.64 \%$, which is more than ever before. At the same time, the share of reports on financing investments from foreign sources has dropped to zero (Table 10).

It should be noted that the most common reason that prevents enterprises from using external investment financing is unacceptable credit conditions: too high interest rates, short-term loans, etc. This reason was mentioned in the spring of 2021 by almost half $(47.41 \%)$ of enterprises (Table 11). This circumstance again casts doubt on the correctness of the decision of the Bank of Russia to increase the interest rate at the time when the domestic economy has not completely overcome the crisis.

An important feature of the current situation is the increased attention of Russian enterprises to the exchange rate of the ruble against the dollar and euro. This is probably due to a noticeable increase in prices in international markets, which has directly affected the costs and incomes of enterprises engaged in active foreign trade operations. In addition, the rise in world prices for exchange commodities such as metal, grain, chemical products has led to the rise in prices for them on the domestic markets as well. As a result, in the spring of 2021, the total share of enterprises for which the significance of the exchange rate of the ruble against the dollar was medium and high was more than two times higher than the total share of enterprises for which the significance of this exchange rate was zero or low $-68.46 \%$ versus $31.54 \%$. At the same time, in 2019 , a similar ratio was approximately $55 \%$ versus $45 \%$ (Table 12). An even more abrupt shift in assessments of the importance of the exchange rate has
Table 5. Answers to the question: "Will your company invest more if interest rates on bank loans are reduced?" (sum of answers $=100 \%$ )

\begin{tabular}{c|c|c|c}
\hline Period & Yes & No & Difficult to say \\
\hline April-May 2020 & 40.40 & 22.10 & 37.50 \\
April-May 2021 & 39.46 & 13.61 & 46.93 \\
\hline
\end{tabular}

Table 6. Answers to the question: "Is your company currently implementing any industrial investment projects?" (sum of answers $=100 \%)$

\begin{tabular}{l|c|c}
\hline \multicolumn{1}{c|}{ Period } & Yes & No \\
\hline April-May 2014 & 58.75 & 41.25 \\
April-May 2015 & 48.39 & 51.61 \\
April-May 2016 & 44.87 & 55.13 \\
April-May 2017 & 54.05 & 45.95 \\
April-May 2018 & 49.57 & 50.43 \\
April-May 2019 & 53.74 & 46.26 \\
April-May 2020 & 59.40 & 40.60 \\
April-May 2021 & 52.94 & 47.46 \\
\hline
\end{tabular}

Table 7. Answers to the question: "Will your company begin to implement industrial investment projects in the next $1-2$ years?" (sum of answers $=100 \%$ )

\begin{tabular}{c|c|c|c}
\hline Period & Yes & No & It is difficult to say \\
\hline April-May 2014 & 52.20 & 14.47 & 33.33 \\
April-May 2015 & 33.99 & 15.69 & 50.32 \\
April-May 2016 & 35.06 & 16.88 & 45.06 \\
April-May 2017 & 41.10 & 13.70 & 45.20 \\
April-May 2018 & 46.96 & 19.13 & 33.91 \\
April-May 2019 & 43.15 & 19.18 & 37.67 \\
April-May 2020 & 42.50 & 14.90 & 42.50 \\
April-May 2021 & 46.71 & 13.82 & 39.47 \\
\hline
\end{tabular}

Table 8. Answers to the question: "How has the financing of production investments of your company from its own funds changed over the past year?" (sum of answers = 100\%)

\begin{tabular}{l|c|c|c}
\hline \multicolumn{1}{c|}{ Period } & $\begin{array}{c}\text { It has } \\
\text { increased }\end{array}$ & $\begin{array}{c}\text { It is almost } \\
\text { unchanged }\end{array}$ & $\begin{array}{c}\text { It has } \\
\text { decreased }\end{array}$ \\
\hline March-April 2011 & 27.46 & 46.11 & 26.43 \\
April-May 2013 & 36.60 & 46.41 & 16.99 \\
April-May 2015 & 20.39 & 34.21 & 45.40 \\
April-May 2017 & 18.62 & 51.72 & 29.66 \\
April-May 2019 & 25.18 & 43.88 & 30.94 \\
April-May 2021 & 17.24 & 36.55 & 46.21 \\
\hline
\end{tabular}

Vol. $32 \quad$ No. $6 \quad 2021$ 
Table 9. Answers to the question: "How has the financing of production investments of your enterprise by external investors changed over the past year?"

\begin{tabular}{l|c|c|c}
\hline \multicolumn{1}{c|}{ Period } & $\begin{array}{c}\text { It has } \\
\text { increased }\end{array}$ & $\begin{array}{c}\text { It is almost } \\
\text { unchanged }\end{array}$ & $\begin{array}{c}\text { It has } \\
\text { decreased }\end{array}$ \\
\hline March-April 2011 & 6.38 & 75.18 & 18.44 \\
April-May 2013 & 9.01 & 64.86 & 26.13 \\
April-May 2015 & 3.70 & 66.67 & 29.63 \\
April-May 2017 & 4.35 & 64.35 & 31.30 \\
April-May 2019 & 8.82 & 67.65 & 23.53 \\
April-May 2021 & 6.78 & 64.41 & 28.81 \\
\hline
\end{tabular}

occurred in terms of the ratio of the ruble to the euro (Table 13).

As in previous years, among the reasons that determine the importance of the exchange rate of the ruble against the dollar and the euro for Russian enterprises, the most often mentioned reasons were the high demand for purchases of imported machinery and equipment (52.31\% of answers), as well as the high share of imports in purchases of raw materials and components (54.62\% of answers).

Over the past two years, the share of answers about the importance of the exchange rate in connection with the conduct of export operations has also slightly increased (Table 14). Perhaps this shift reflects the export successes that have been achieved in recent years by many Russian enterprises in the agricultural sector, mechanical engineering, food and chemical industries.

As for the wishes that enterprises expressed about the further dynamics of the exchange rate, the share of respondents favoring a strengthening of the ruble has increased sharply in 2021 compared to 2019 from $31.68 \%$ to $47.95 \%$ (Table 15). Apparently, many domestic enterprises are well aware that it is possible to

Table 10. Answers to the question: "What are the sources of financing for investment projects of your enterprise?" (sum of answers $>100 \%$ )

\begin{tabular}{|c|c|c|c|c|c|c|c|}
\hline \multirow[b]{2}{*}{ Period } & \multirow{2}{*}{$\begin{array}{l}\text { Own funds } \\
\text { of the } \\
\text { enterprise }\end{array}$} & \multicolumn{2}{|c|}{ Target financing } & \multicolumn{2}{|r|}{ Loans } & \multirow{2}{*}{$\begin{array}{l}\text { Foreign loans } \\
\text { or direct } \\
\text { foreign } \\
\text { investments }\end{array}$} & \multirow[b]{2}{*}{$\begin{array}{l}\text { Other } \\
\text { sources }\end{array}$} \\
\hline & & $\begin{array}{c}\text { from the } \\
\text { federal budget }\end{array}$ & $\begin{array}{c}\text { from the } \\
\text { regional budget }\end{array}$ & $\begin{array}{c}\text { Russian } \\
\text { banks }\end{array}$ & $\begin{array}{c}\text { or direct investments } \\
\text { of other Russian } \\
\text { enterprises }\end{array}$ & & \\
\hline March-April 2011 & 83.15 & 4.49 & 6.18 & 43.26 & 2.81 & 2.25 & 6.18 \\
\hline April-May 2013 & 89.19 & 10.81 & 1.35 & 38.51 & 4.73 & 2.03 & 5.41 \\
\hline April-May 2015 & 89.12 & 6.12 & 4.76 & 36.73 & 2.72 & 2.72 & 2.72 \\
\hline April-May 2017 & 93.15 & 10.96 & 6.85 & 34.25 & 4.11 & 2.05 & 3.42 \\
\hline April-May 2019 & 88.46 & 6.92 & 8.46 & 36.15 & 3.85 & 1.54 & 5.38 \\
\hline April-May 2021 & 86.99 & 11.64 & 8.90 & 43.15 & 5.48 & 0.00 & 0.68 \\
\hline
\end{tabular}

Table 11. Answers to the question: "What reasons prevent your company from more actively using external financing of investments?" (sum of answers $>100 \%$ )

\begin{tabular}{|c|c|c|c|c|c|c|c|}
\hline Period & $\begin{array}{c}\text { Unacceptable } \\
\text { financial } \\
\text { conditions on their } \\
\text { part (too high } \\
\text { percentage, } \\
\text { willingness to issue } \\
\text { loans only for a } \\
\text { short time, etc.) }\end{array}$ & \begin{tabular}{|c|} 
Unacceptable \\
legal conditions \\
(underestimated \\
responsibility on \\
their part and \\
overestimated \\
responsibility on \\
the part of the \\
enterprise, etc.)
\end{tabular} & $\begin{array}{c}\text { Unacceptable } \\
\text { conditions } \\
\text { for control } \\
\text { over property }\end{array}$ & $\begin{array}{c}\text { Unacceptable } \\
\text { degree of } \\
\text { interventions } \\
\text { in management } \\
\text { of production }\end{array}$ & $\begin{array}{c}\text { By and large, } \\
\text { almost none } \\
\text { of the external } \\
\text { investors have } \\
\text { a significant } \\
\text { amount of } \\
\text { money at the } \\
\text { moment }\end{array}$ & \begin{tabular}{|} 
Objective \\
degree of \\
readiness of our \\
enterprise is still \\
insufficient to \\
receive foreign \\
investments
\end{tabular} & Other \\
\hline March-April 2011 & 49.41 & 10.00 & 14.12 & 5.29 & 12.94 & 32.94 & 11.18 \\
\hline April-May 2013 & 56.83 & 12.23 & 15.11 & 9.35 & 5.76 & 35.97 & 7.91 \\
\hline April-May 2015 & 54.96 & 11.45 & 14.50 & 8.40 & 14.50 & 32.84 & 7.63 \\
\hline April-May 2017 & 55.56 & 14.29 & 9.52 & 4.76 & 16.67 & 29.37 & 11.11 \\
\hline April-May 2019 & 49.15 & 14.41 & 7.63 & 5.08 & 11.02 & 32.20 & 14.41 \\
\hline April-May 2021 & 47.41 & 18.10 & 16.38 & 11.21 & 18.10 & 35.34 & 3.45 \\
\hline
\end{tabular}


Table 12. Answers to the question: "What is the significance of the exchange rate of the ruble against the US dollar for your enterprise?" ( sum of answers $=100 \%$ )

\begin{tabular}{l|r|c|c|c}
\hline \multicolumn{1}{c|}{ Period } & Zero & Small & Medium & Large \\
\hline April-May 2012 & 20.55 & 36.99 & 26.03 & 16.43 \\
November-Decem- & 21.91 & 35.96 & 24.72 & 17.41 \\
ber 2013 & & & & \\
April-May 2015 & 7.74 & 20.64 & 29.68 & 41.94 \\
November-Decem- & 17.18 & 22.70 & 30.06 & 30.06 \\
ber 2016 & 9.70 & 26.12 & 35.08 & 29.10 \\
April-May 2018 & 16.46 & 28.05 & 29.88 & 25.61 \\
November-Decem- \\
ber 2019
\end{tabular}

Table 13. Answers to the question: "What is the significance of the exchange rate of the ruble against the euro for your company?" (sum of answers $=100 \%)$

\begin{tabular}{l|r|c|c|c}
\hline \multicolumn{1}{c|}{ Period } & Zero & Small & Medium & Large \\
\hline April-May 2012 & 19.73 & 35.37 & 27.89 & 17.01 \\
November-December 2013 & 23.60 & 38.76 & 23.03 & 14.61 \\
April-May 2015 & 18.07 & 21.29 & 30.32 & 30.32 \\
November-December 2016 & 15.15 & 27.27 & 31.52 & 26.06 \\
April-May 2018 & 9.70 & 34.33 & 31.34 & 24.63 \\
November-December 2019 & 23.64 & 30.91 & 28.48 & 16.97 \\
April-May 2021 & 12.75 & 22.82 & 30.87 & 33.56 \\
\hline
\end{tabular}

mitigate the losses associated with the rise in prices for imported products precisely by increasing the ruble exchange rate.
Working in the pandemic has certainly influenced the behavior patterns of enterprises. One of the natural consequences that are caused by the new circumstances is the wider use of remote employment. Moreover, as the survey data show, remote employment is now more often used not only in relation to individual employees, but also in relation to entire subdivisions. In particular, if we compare 2021 with 2017, then the share of respondents who reported the presence of subdivisions in other settlements of Russia has increased from 24.66 to $30.26 \%$ (Table 16). In addition, the share of enterprises that are planning to create new remote subdivisions, or at least are thinking about such an opportunity is gradually growing (Table 17).

In addition, there has been an increase in the share of enterprises that use outsourcing - the transfer of part of their work to external performers on a contractual basis. This is usually done to reduce costs and improve quality [8], but in the pandemic this also helps to reduce the health risks of employees. As a result, the share of responses about the use of outsourcing has increased from $34.97 \%$ in 2017 to $39.33 \%$ in 2021 (Table 18).

As part of the survey, the study of topics related to the processes of sustainable development was continued. To this end, in the spring of 2021 respondents were asked a number of questions about the state of affairs in the field of industrial waste and recycling of raw materials. The problem of industrial waste causing great harm to the environment and human health affects a variety of socio-economic processes and remains invariably relevant [9]. Despite the presence in the Russian legislation of a number of normative legal acts governing the management of production

Table 14. Answers to the question: "What reasons determine for you the importance of the exchange rate of the ruble against the dollar and the euro?" (sum of answers $>100 \%$ )

\begin{tabular}{|c|c|c|c|c|c|}
\hline Period & $\begin{array}{c}\text { Noticeable share } \\
\text { of exports in sales } \\
\text { of products }\end{array}$ & $\begin{array}{l}\text { Significant share } \\
\text { of imports in the } \\
\text { procurement of raw } \\
\text { materials and } \\
\text { components }\end{array}$ & $\begin{array}{c}\text { High demand } \\
\text { for purchases of } \\
\text { imported machinery } \\
\text { and equipment }\end{array}$ & $\begin{array}{c}\text { High level } \\
\text { of competition } \\
\text { with foreign } \\
\text { manufacturers on } \\
\text { Russian markets }\end{array}$ & $\begin{array}{c}\text { High level } \\
\text { of competition } \\
\text { with foreign } \\
\text { manufacturers on } \\
\text { foreign markets }\end{array}$ \\
\hline April-May 2012 & 18.18 & 53.72 & 42.15 & 23.97 & 5.78 \\
\hline $\begin{array}{l}\text { November- } \\
\text { December } 2013\end{array}$ & 15.63 & 55.47 & 43.75 & 20.31 & 3.91 \\
\hline April-May 2015 & 17.04 & 69.63 & 34.81 & 28.89 & 5.19 \\
\hline $\begin{array}{l}\text { November- } \\
\text { December } 2016\end{array}$ & 15.56 & 60.74 & 43.70 & 17.04 & 4.44 \\
\hline April-May 2018 & 19.35 & 67.74 & 49.19 & 16.94 & 4.84 \\
\hline $\begin{array}{l}\text { November- } \\
\text { December } 2019\end{array}$ & 17.52 & 61.31 & 48.91 & 14.60 & 7.30 \\
\hline April-May 2021 & 20.00 & 54.62 & 52.31 & 17.69 & 11.54 \\
\hline
\end{tabular}


Table 15. Answers to the question: "What development of events in the foreign exchange market is currently more profitable for your company?" (sum of answers =100\%)

\begin{tabular}{l|c|c|c|c}
\hline \multicolumn{1}{c|}{ Period } & $\begin{array}{c}\text { Weakening } \\
\text { of the ruble } \\
\text { exchange rate }\end{array}$ & $\begin{array}{c}\text { Stability } \\
\text { of the ruble } \\
\text { exchange rate }\end{array}$ & $\begin{array}{c}\text { Strengthening } \\
\text { of the ruble } \\
\text { exchange rate }\end{array}$ & $\begin{array}{c}\text { Changes in the ruble exchange } \\
\text { rate are not of great importance } \\
\text { for us }\end{array}$ \\
\hline April-May 2014 & 14.91 & 44.10 & 26.71 & 14.28 \\
April - May 2016 & 13.07 & 38.56 & 36.60 & 11.77 \\
November-December 2016 & 8.86 & 44.94 & 37.97 & 8.23 \\
April - May 2017 & 14.38 & 42.47 & 28.77 & 14.38 \\
April-May 2018 & 9.38 & 54.69 & 33.59 & 2.34 \\
November-December 2019 & 10.56 & 44.72 & 31.68 & 13.04 \\
April-May 2021 & 8.22 & 38.36 & 47.95 & 5.47 \\
\hline
\end{tabular}

and consumption waste (PCW) and the use of secondary raw materials in production ${ }^{2}$, accounting for the generation and use of waste does not cover all processes, and Russian enterprises are not yet active enough in the use of secondary resources.

In addition, the volumes of PCW recycling and neutralization in Russia are significantly lower than the volume of its generation, even despite the fact that in certain years the growth rates of $\mathrm{PCW}$ recycling and neutralization outstripped the growth rates of its generation (Fig. 1).

The above statistics show that the environmental problems associated with the accumulation of waste are aggravating in the country, and the scale of lost economic benefits is growing, since more and more significant volumes of PCW are not involved in repeated economic circulation (recycling) in the form of secondary resources [13].

Nevertheless, there is no doubt that there are economic prerequisites for expanding the use of secondary raw materials by Russian enterprises. For example, energy consumption in the production of secondary aluminum is 20 times less than in case of its extraction from primary raw materials, and this ratio in the production of ferrous metals is threefold. Moreover, in both cases, the volume of harmful emissions is significantly reduced [14].

In this regard, it was important to find out how intensively Russian enterprises process their waste into secondary raw materials for further use, whether they use these raw materials in the manufacture of their products, what benefits they receive and what difficulties they face.

The survey has shown that secondary raw materials are used by about a quarter of enterprises in the man-

\footnotetext{
${ }^{2}$ Starting with the FL "On Production and Consumption Waste" [10] and ending with the Strategy for the Development of Industry for Processing, Recycling, and Neutralization of the Production and Consumption Waste for the Period until 2030 [11].
}

ufacture of their products. In particular, secondary raw materials are used in the chemical industry, agriculture, in the production of cast iron, batteries and their components, paper and cardboard, plastic products, etc. Another $6.25 \%$ of enterprises intend to use secondary raw materials in their production in the future. For almost $60 \%$ of enterprises, the use of secondary raw materials is impossible for technical reasons. A much smaller share of enterprises (11.11\%) do not use secondary raw materials, since this does not bring tangible benefits (Table 19).

Table 16. Answers to the question: "Does your enterprise have geographically separate subdivisions in other settlements of Russia?" (sum of answers $=100 \%$ )

\begin{tabular}{c|c|c}
\hline Period & Yes & No \\
\hline April-May 2017 & 24.66 & 75.34 \\
April-May 2021 & 30.26 & 69.74 \\
\hline
\end{tabular}

Table 17. Answers to the question: "Does your enterprise plan to open new territorially separate subdivisions in other settlements of Russia?" (sum of answers $=100 \%$ )

\begin{tabular}{c|c|c|c}
\hline Period & Yes & No & It is difficult to say \\
\hline April-May 2017 & 6.90 & 86.20 & 6.90 \\
April-May 2021 & 9.80 & 72.55 & 17.65 \\
\hline
\end{tabular}

Table 18. Answers to the question: "Does your enterprise use outsourcing (transfer to external organizations on a contractual basis) of some auxiliary functions and production operations that were previously performed at the enterprise itself?" (sum of answers = 100\%)

\begin{tabular}{c|c|c|c}
\hline Period & Yes & No & $\begin{array}{c}\text { No, but this is planned } \\
\text { in the future }\end{array}$ \\
\hline April-May 2017 & 34.97 & 61.54 & 3.49 \\
April-May 2021 & 39.33 & 56.67 & 4.00 \\
\hline
\end{tabular}




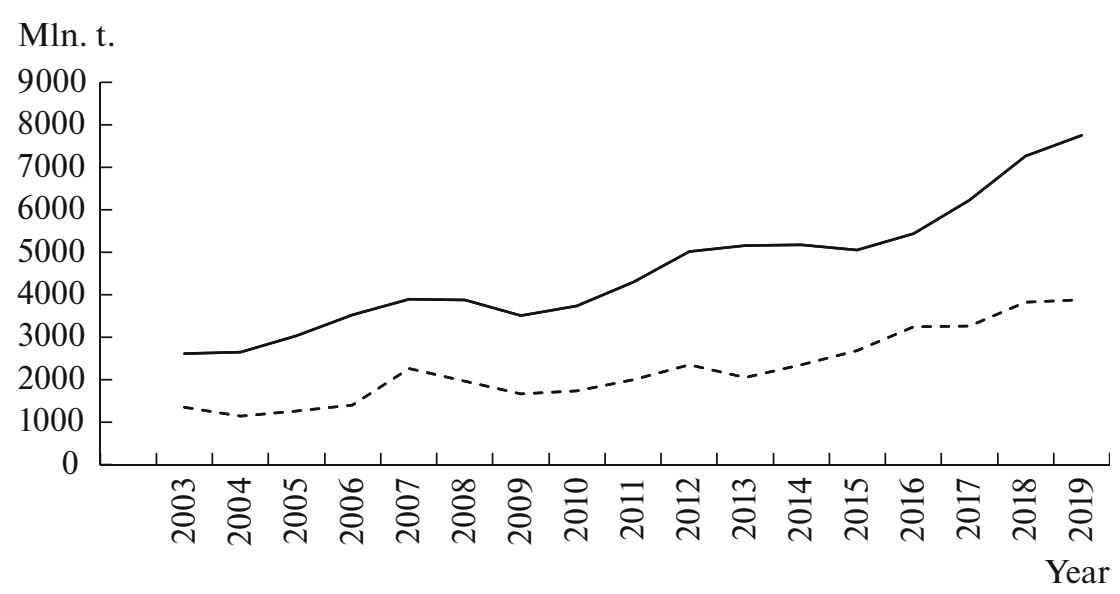

Fig. 1. Formation, recycling, and neutralization of production and consumption waste (PCW). Solid line-formation of PCW; dotted line-recycling and neutralization of PCW. Source: Rosstat [12].

The majority of enterprises (about 55\%) consume approximately the same amount of secondary raw materials as $3-5$ years ago. The shares of enterprises that have increased their consumption of secondary raw materials and have reduced their use over the past $3-5$ years are approximately equal (Table 20 ). In other words, there is yet no talk of positive shifts in this area.

Meanwhile, the majority of enterprises (70\%) are not yet engaged in the processing of their industrial waste into secondary raw materials (Table 21). Accordingly, slightly more than a quarter of the surveyed enterprises process their industrial waste for further use.

Enterprises that process their waste into secondary raw materials most often sell them on the market to other users and/or use them in their own production $(48 \%)$. There is also a noticeable share of enterprises supplying secondary raw materials to other users free of charge: they include representatives of a wide variety of economic activities, varying from the produc- tion of bakery products to the production of frame cranes (Table 22).

Enterprises most often process paper waste, plastic, metals, old accumulators and batteries into recyclable raw materials. Glass, wood waste, concrete products, organochlorine raw materials, fuels and lubricants, artificial leather, etc. are also processed, although much less frequently (Fig. 2).

For the majority of the surveyed enterprises $(63.86 \%)$, which are engaged in the processing of their industrial waste into secondary raw materials, the volume of processing has remained approximately at the same level over the past 3-5 years (Table 23). Approximately $15 \%$ of enterprises have increased the volume of processed waste, while approximately $20 \%$ have decreased it.

The main benefit that enterprises receive from the use of secondary raw materials in the manufacture of products or from the processing of production waste is to reduce costs $(70 \%)$.

Table 19. Answers to the question: "Does your company use secondary raw materials in the manufacture of its products?" (sum of answers $=100 \%$ )

\begin{tabular}{c|c|c|c|c}
\hline Period & Yes & $\begin{array}{c}\text { No, because it does not } \\
\text { bring us tangible benefits }\end{array}$ & $\begin{array}{c}\text { No, because the use of secondary raw } \\
\text { materials is unacceptable for our production }\end{array}$ & $\begin{array}{c}\text { No, but it is going } \\
\text { to use them in the future }\end{array}$ \\
\hline April-May 2021 & 23.61 & 11.11 & 59.03 & 6.25 \\
\hline
\end{tabular}

Table 20. Answers to the question: "If your enterprise uses secondary raw materials in production, how has their volume changed over the past $3-5$ years?" (sum of answers $=100 \%$ )

\begin{tabular}{c|c|c|c}
\hline Period & $\begin{array}{c}\text { We have begun to use more } \\
\text { secondary raw materials }\end{array}$ & $\begin{array}{c}\text { We consume approximately } \\
\text { the same amount of secondary } \\
\text { raw materials as 3-5 years ago }\end{array}$ & $\begin{array}{c}\text { The volume of secondary raw } \\
\text { materials we used in production } \\
\text { has decreased }\end{array}$ \\
\hline April-May 2021 & 21.57 & 54.90 & 23.53 \\
\hline
\end{tabular}


Table 21. Answers to the question: "Does your company process its waste into secondary raw materials for further use?" (sum of answers $=100 \%$ )

\begin{tabular}{c|c|c|c}
\hline Period & Yes & No & No, it intends to process them in the future \\
\hline April-May 2021 & 26.43 & 70.00 & 3.57 \\
\hline
\end{tabular}

Table 22. Answers to the question: "If your company processes its waste into secondary raw materials, how do you deal with them?" (sum of answers >100\%)

\begin{tabular}{c|c|c|c|c}
\hline \multicolumn{1}{c|}{ Period } & $\begin{array}{c}\text { We sell them } \\
\text { on the market }\end{array}$ & $\begin{array}{c}\text { We use them in our own } \\
\text { production }\end{array}$ & $\begin{array}{c}\text { We supply them free } \\
\text { of charge to other users }\end{array}$ & $\begin{array}{c}\text { Other } \\
\text { April-May 2021 }\end{array}$ \\
\hline
\end{tabular}

The respondents much less often indicated an improvement in the company's image, compliance with international standards for greening and a decrease in claims from the state and society (Table 24).

The most significant difficulty faced by enterprises in this process is the lack of available external operators for the processing, purchase and sale of wastethis was indicated by almost $42 \%$ of respondents (Table 25). Another notable problem is the lack of the necessary equipment/technologies for processing in production (33\% of responses). In addition, the respondents quite often pointed to the absence of bills accompanying the waste recycling reform $(21 \%)$. At the same time, some enterprises reported that they did not have any difficulties with waste processing. Some other enterprises, on the contrary, spoke negatively about the upcoming reforms in the field of waste management with the participation of "RosRAO".

Taking into account the results of the survey, it can be argued that the task of accelerating the transition to a circular economy based on the use of secondary resources in production makes it necessary to ensure the transition from general institutional decisions to specific mechanisms for managing planned transformations [15], remove a number of restrictions, which are indicated by enterprises, and develop a number of additional incentive measures (for example, introduce tax incentives for enterprises that actively work in this area) $[16,17]$.

The main conclusions of the survey are as follows:

1. In the spring of 2021, the share of enterprises that have come to the conclusion that they have not suffered from the consequences of the COVID-19 pandemic has increased noticeably-up to $22.9 \%$.

2. A noticeable contribution to the improvement of the situation has been made by the anticrisis policy of the state. By the spring of 2021, 30.46\% of enterprises surveyed have already received assistance from the federal authorities, and $8.90 \%$ of enterprises have received assistance from regional authorities. As a result, in the spring of 2021, Russian enterprises rated the quality of the state anticrisis policy significantly higher than in the spring of 2020.

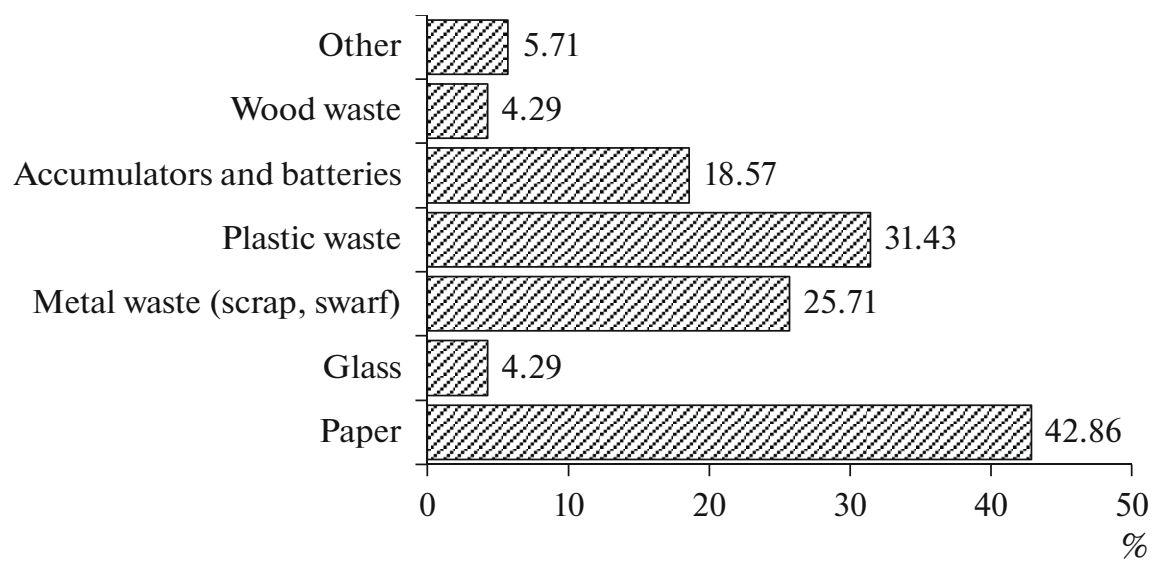

Fig. 2. Answers to the question "What waste does your enterprise process into secondary raw materials?" (sum of answers $>$ $100 \%)$. 
Table 23. Answers to the question: "How has the volume of processing your production waste into secondary raw materials changed over the past $3-5$ years?" (sum of answers $=100 \%$ )

\begin{tabular}{l|c|c|c}
\hline Period & $\begin{array}{c}\text { The volume of waste that we } \\
\text { process into secondary raw } \\
\text { materials has increased }\end{array}$ & $\begin{array}{c}\text { The volume of processed } \\
\text { waste has remained at about } \\
\text { the same level }\end{array}$ & $\begin{array}{c}\text { The volume of processed } \\
\text { waste has decreased }\end{array}$ \\
\hline April-May 2021 & 15.66 & 63.86 & 20.48 \\
\hline
\end{tabular}

Table 24. Answers to the question: "What benefits does your company receive from the use of secondary raw materials in the manufacture of products and/or from the processing of its waste into secondary raw materials?” (sum of answers $>100 \%$ )

\begin{tabular}{c|c|c|c|c}
\hline Period & Cost reduction & $\begin{array}{c}\text { Improvement of the enterprise image, compliance } \\
\text { with international standards for greening }\end{array}$ & $\begin{array}{c}\text { Decrease in claims } \\
\text { from the state and society }\end{array}$ & Other \\
\hline April-May 2021 & 70.00 & 18.57 & 18.57 & 4.29 \\
\hline
\end{tabular}

Table 25. Answers to the question: "What difficulties does your company face in the process of processing its waste into secondary raw materials and/or using secondary raw materials in production?" (sum of answers $>100 \%$ )

\begin{tabular}{c|c|c|c|c}
\hline Period & $\begin{array}{c}\text { Lack of the necessary } \\
\text { equipment/technologies } \\
\text { for processing at the } \\
\text { production site }\end{array}$ & $\begin{array}{c}\text { Lack of available external } \\
\text { operators for the processing, } \\
\text { purchase and sale of waste }\end{array}$ & $\begin{array}{c}\text { Lack of bills accompanying the waste } \\
\text { recycling reform/the presence of bills } \\
\text { hindering the waste recycling reform }\end{array}$ & Other \\
\hline April-May 2021 & 32.56 & 41.86 & 20.93 & 6.98 \\
\hline
\end{tabular}

3. Despite the revival in the Russian economy, there were no clear signs of increased investment activity on the part of enterprises in the spring of 2021. This is largely due to the lack of their own financial resources and the high cost of loans.

4. The acceleration in the growth of prices, including for imported products, has significantly increased the attention of Russian enterprises to the dynamics of the ruble exchange rate. At the same time, the overwhelming majority of enterprises favor strengthening or stability of the ruble exchange rate.

5. Russian enterprises are increasingly using outsourcing and/or creating geographically separate subdivisions. Apparently, the COVID-19 pandemic has accelerated this process.

6. About a quarter of the surveyed enterprises process industrial waste into secondary raw materials and use them in the manufacture of their products. At the same time, there is a lack of significant positive shifts in this area, which indicates the insufficient effectiveness of measures for the development of the market of secondary material resources.

7. The overwhelming majority of enterprises are primarily driven by economic interest; secondary raw materials are most often used in their own production, or sold on the market. If enterprises do not see economic benefits, they are unlikely to be involved in the processing of industrial waste and use secondary raw materials in their production. In this regard, it seems necessary to develop a system of state support in order to increase the interest of the Russian real sector in solving the problems of production waste and the use of secondary raw materials.

\section{ACKNOWLEDGMENTS}

G.P. Belyakova, L.I. Pisareva, N.I. Titova, R.A. Galetskaya, and O.Yu. Galetskaya also took part in the preparation of the article. We express gratitude for help in organizing the survey to E.K. Vorobei (Sochi State University), S.V. Terebova (Vologda Scientific Center of the RAS), N.N. Evchenko (South Federal University), and N.Ya. Krivonosova (Baikal State University).

\section{REFERENCES}

1. Center for Macroeconomic Analysis and Short-Term Forecasting (CMASF), Foreign trade plots, 2021. http://www.forecast.ru/_ARCHIVE/WW_MONS/ 2021/13_2021.pdf.

2. V. N. Borisov and O. V. Pochukaeva, "Analysis and forecast of the competitiveness of Russian investment technology in the far abroad markets," Ekon. i Sots. Peremeny: Fakty, Tendentsii, Prognoz 14 (2), 43-58 (2021). 
3. FSGS of Russia. Information on the socio-economic situation in Russia-2021.

https://gks.ru/bgd/free/B21_00/main.htm.

4. Center for Macroeconomic Analysis and Short-Term Forecasting (CMASF), Macroeconomic trends review. June 9 (2021). http://www2.forecast.ru/_ARCHIVE/Mon_MK/2021/macro17.pdf.

5. V. A. Ilyin and M. V. Morev, "Effectiveness of "manual" government management. Strength test - 2020," Ekon. Sots. Peremeny: Fakty, Tendentsii, Prognoz 13 (2), 9-24 (2020).

6. A. A. Yakovlev, M. G. Kuzyk, and I. A. Sedykh, "Impact of the pandemic and the state anti-crisis policy on the Russian IT sector," EKO 51 (5), 8-28 (2021). https://doi.org/10.30680/ECO0131-7652-2021-5-8-28

7. E. G. Leonidova, "Tourism in Russia in the context of covid-19: assessing the economic effect of stimulating demand for the country and regions," Ekon. Sots. Peremeny: Fakty, Tendentsii, Prognoz 13 (2), 59-74 (2020).

8. K. V. Yankov, "Territorial dispersal of jobs as a factor of spatial development of the economy," Probl. Prognozirovaniya, No. 1 (166), 68-75 (2018).

9. I.A. Budanov, A. Yu. Kolpakov, D. A. Polzikov et al., Economic Aspects of Modernization of the Waste Management Sector in Russia. Scientific Report (Nauka, Moscow, 2020) [in Russian].

10. No. 89-FZ of June 24, 1998 "On production and consumption waste," Consultant Plus. http://www.consultant.ru/document/cons_doc_LAW_19109/.
11. Industry development strategy for processing, recycling and disposal of production and consumption waste for the period until 2030. http://government.ru/docs/31184/.

12. Formation, utilization, neutralization and disposal of production and consumption waste in the Russian Federation. Rosstat. https://rosstat.gov.ru/storage/mediabank/oxr_otxod3.xls.

13. R. S. Fesenko, Role of recycling in balanced regional development. Abstract of thesis, Cand. Sci. (Econ.) Dissertation, St. Petersburg, 2011, p. 24.

14. Escape routes have been selected. Rossiyskaya Gazeta. https://rg.ru/2020/07/06/dlia-sozdaniia-otrasli-pererabotki-othodov-nuzhna-aktivnost-naseleniia.html.

15. M. F. Zamyatina, "Green" and circular economy as a factor in the transformation of the socio-economic system of the region," in Strategies for the Development of Entrepreneurship in Modern Conditions of Collection of Scientific Papers of the IV National (with International Participation) Scientific and Practical Conference, pp. 327-330 (2020) [in Russian].

16. Economic Aspects of Modernization of the Waste Management Sector in Russia (Nauka, Moscow, 2020) [in Russian].

17. M. V. Turanova, "Problems of reforming the production and consumption waste management system in Russia" in Problems of Transformation and Regulation of Regional Socio-Economic Systems. Collection of Scientific Papers (St. Petersburg, 2020). pp. 39-41.

Translated by L. Solovyova 